\title{
IN DEFENSE OF SPACE ART: THE ROLE OF THE ARTIST IN SPACE EXPLORATION
}

\author{
ROGER F. MALINA \\ Executive Director, Journal LEONARDO \\ 2020 Milvia Street, Berkeley, CA 94704, U.S.A. \\ and Staff Astronomer, Space Sciences Laboratory, \\ University of California, Berkeley, CA 94720
}

\begin{abstract}
Artworks will be built in space as the frequency and range of space missions increase. Artists have proposed artworks to be installed in space and have worked with space agencies to begin planning for such projects; a few space art projects have been completed. It is argued that artworks should be reviewed with the same constraints as all other space artifacts. It is unlikely that artworks will ever pose the kind of environmental threat that already exists from scientific, commercial and military activities; the cultural value of creating some space art balances the associated costs and risks. Artworks visible to global audiences can be conceived and have been proposed; it is these proposals that have concerned astronomers. Public space art should be subject to a process of public scrutiny similar to that of earth-based public art works. Most space art will involve interdisciplinary teams of artists, scientists and engineers; these projects offer the possibility of artists providing novel ideas and approaches that will be of interest in other applications. Artists in the past have played crucial roles in promoting space exploration, in literature, film and the plastic arts. They have also explored the negative aspects and risks. In the future it is inevitable and desirable that artmaking be included in planned space activities.
\end{abstract}

\section{INTRODUCTION}

I am not an artist, but as the Editor of an art journal and a working astronomer, I would like to offer a defense of space art. I hope that in future, artists and astronomers will work together to create a new art of the future space art. Artists and astronomers are natural allies in the peaceful exploration of space. In a public opinion survey commissioned by NASA (1) and carried out by James Pridgeon in 1983, it was found that artists were not only enthusiastic supporters of NASA's proposed artist in space program, but were also stronger supporters of space exploration than the general population.

A young musical composer, Larry Polansky, has expressed his vision this way: "We must leave the planet, and soon. The scope of discovery, the sheer quantity of newness that lies ahead of us is, to be almost ridiculously understated, unparalleled in human history. Along with the physical and scientific wonders beyond the earth's atmosphere lies an equally rich inspirational and ideological source for art and the advancement of human consciousness. It's not that we 
simply need more room to live - we need more room to think. It's not simply that we can learn about 'things' by going into space - but that we can learn about ourselves. When the first human inhabits another planet, there will be a revolution in art and ideas unlike any we have ever seen, and probably unlike any we will see again until another dimension of equal magnitude (time? physicality?) is breached." (2)

I will use as my definition of fine art, expanding on the definition offered by F. J. Malina in an article on space art (3):"The discipline that has the purpose, by means of artifacts, of stimulating human emotions and of deepening emotional perception or understanding of selected portions of the human environment and human consciousness."

Artmaking is a research activity whose goal is to generate human made objects, events or processes. The purpose of these artifacts is to affect human perceptions. This definition does not tie art to the institutional location of artifacts, the lifetime of the artifact, nor to the nominal profession of the commercial art marketplace, nor need art be a commodity.

I believe that the most significant art of our time, which can be called contemporary art, is art that could not have been produced in any previous epoch. The creation of contemporary art is inextricably tied to the process of creating human civilization. Within this perspective, artmaking will occur as part of space exploration, and in fact artmaking must be encouraged in space as one of the ways without which, in the long run, human use of space will be incomplete and unsuccessful.

I feel that it is important that the context of the contemporary arts as vital to a successful space program, needs to be stated at the outset. The issue is not whether there will be space art, but when will significant space art be created. Yet in the public opinion carried out by Pridgeon (1), 30\% of the scientists polled indicated that they thought that space art was frivolous; this was as opposed to $7 \%$ of the artists polled. The concern has been stated that the line between art and commercial advertising is hard to delineate, and the spectre of a sky full of orbiting commercial signs has been raised. This is not such an unlikely vision, since advertising in space with the potential to reach a global market is already economically competitive with other advertising media. The advertising budget during the recent Olympic games, for instance, would in fact have been adequate to put advertising displays in space.

I would argue that the approval process for highly visible space art should be no different than any other public art, except that the public concerned is a global one. The United Nations is the appropriate forum for discussion of the suitability of public art projects, or advertising, in space. Astronomers have no particular expertise in this regard, and are but one of the public communities which would be affected by space art. The International Astronomical Union has been alerted to space art projects because some of the projects proposed would clearly cause unacceptable light pollution to ground-based observatories. It is appropriate that international astronomers' organizations be consulted as part of the review process of space art, but I do not believe that they should have a "veto" power. Both the International Astronomical Union and the International Academy of Astronautics have issued resolutions seeking to limit space art projects. Similarly, artists' groups have issued resolutions calling for the promotion of space art. It is desirable that astronomers establish the constraints they wish to see established on objects visible from the ground, whatever the intended use of these objects. 
For instance, it has been pointed out that the proposed U.S. Space Station could cause more light pollution than any of the space art objects proposed.

\section{TYPES OF SPACE ART}

I will define space art as contemporary art which relies for its implementation on participation in space activity. In some sense, space art is an extension of the environmental art and land art movements where artists, such as Robert Smithson and James Turrell, have used large sections of the earth as the raw material for their art objects. Some 200 artists have signed the Sky Art Manifesto (4) (drawn up under the leadership of Otto Piene, Elizabeth Goldring and Lowry Burgess) which calls for the establishment of alliances with space agencies to assist in the establishment of space art projects.

The kinds of space art include:

1) Art which makes use of new techniques, materials or sensory experiences generated as by-products of space exploration.

2) Art which expresses the new psychological experiences or new philosophical conceptions developed through space exploration.

3) Art in space made to be viewed from earth.

4) Art on the earth to be viewed from space.

5) Art in space to be used in space or viewed from space.

For the purposes of this paper, I will discuss only the last three types, since these will have impacts on astronomers and space astronomy either through effects of light pollution, electromagnetic interference or space debris. For a discussion of the first two types, see the article by Frank J. Malina (3).

\section{ART IN SPACE MADE TO BE VIEWED FROM EARTH}

There have been a number of man-made objects visible from earth beginning with the Sputnik and Echo balloon satellites; this visible evidence of our escape into space has had a world-wide cultural impact on people from the most remote to the most urban locations. Artists immediately began visualizing art works to be located in space and visible from the ground. For instance, Albert Notarbolo (5) in 1971 proposed a number of orbiting structures which could combine artistic and technological goals, most of which used reflected sunlight to make them visible on earth. There have been a succession of proposals since then, including a number made as part of the Sky Art conferences (4) by James Pridgeon in 1983 and 1988, Egge in 1984, the Eiffel proposals in 1986, and a Canadian collective in 1987/88.

In the early 1980s, NASA initiated an innovative Artist in Space program to involve artists in the Space Shuttle and Space Station. A number of courageous administrators saw several projects to completion in spite of significant political and public criticism. NASA launched Joseph McShane's Get Away Special (G.A.S.) Cannister on the U.S. Space Shuttle in 1984; the artwork contained a system of spheres and was used nominally as a materials coating experiment, the 
original motivation being artistic. Before the Challenger explosion, NASA had approved several other G.A.S. can art projects. The first Standard Launch Services Agreement was, in fact, signed in 1982 with Joe Davis of M.I.T.'s Center for Advanced Visual Studies (6) for a work entitled "Ruby Falls." The work was to create artificial auroras visible from the ground using a pulsed electron gun; the work would have lasted the duration of the week-long shuttle flight and would have been used for scientific studies of the shuttle environment. Another approved project originally scheduled to fly in 1986 was by artist Lowry Burgess and was titled "Boundless Cubic Lunar Aperture" (7) and included holograms and cubes made from all the elements known to science. Another approved GAS can project was "Lightflight" by artist Al Wunderlick in collaboration with Joe Davis (6). Joseph McShane had two further flights manifested on the shuttle: one a low earth-orbiting reflecting sculpture and the other a sculpture which would have activated ground station sculptures as it passed over. Unfortunately, due to the explosion of the Challenger, it is unlikely that any of these artworks will be realized, since the climate for non-scientific uses of the shuttle has changed.

On June 30,1986, the Eiffel Corporation announced a competition for innovators to design an object which, when launched into space, would be durable as well as visible to the naked eye from the ground and from as many countries as possible (8). While the object would be allowed to transmit or relay messages, it had to have no commercial or military function, though it might contribute to the development of space research. The competition generated 99 entries and from these, 12 were chosen.

The winning entry, "L'Anneau Lumiere" was by the Groupe Spirale (Alain Coquet, Jerome Gerber, Jean Jacques Leonard, Alain Robert and Jean Waniowski) and Jean Pierre Pommereau, and was a ring of 100 balloons, 6 metres in diameter spaced every 240 meters around a circle framed by a tube $24 \mathrm{Km}$ in circumference. The other prize winners in order of merit were "Arsat" by Pierre Compte and Christian Marchal (9), "Space Disk" by Dieter Kassing, "L'Etoile Eiffel" by Reiner Klett and Gunter Rochelt, "The Space Chronometer" by Chris Coles and Alan Jefferson (10), "L'Arche de Lumiere" by J. Rougherie and J. Hirou, "A Monument Proposal" by Carlton B. Morgan, "La Grande Aiguille" by Joelle Chipaux, "1989 Ulysse La Tour Eiffel de L'Espace" by J. L. Mollard, A. Robert and J. J. Killian, "La Tour Eiffel de l'Espace" by N. J. Stewart, "L'Arc en Espace" by Peter von Ballmoos, "Marianne" by Eric Anderson, Niels Lund and Kurt Cleff. The titles of these entries gives a clear idea of the kinds of sculptures proposed.

More recently, James Pridgeon (11) has made a proposal to the Goodwill Games to launch a flotilla of tethered balloons which would create a new "constellation" in the night sky. The sculpture would be created in the U.S. and launched by the Soviets as an act of international collaboration. Pridgeon takes cognizance of the potential objections of astronomers by specifying that his sculpture would minimize the impact on astronomers, and his designing would minimize space debris. In low earth orbit the sculpture would be visible only at dawn and dusk and re-enter rapidly. He has suggested that the sculpture could be equipped with a beacon to alert ground-based observatories when the sculpture appears over the horizon. A beacon frequency that does not interfere with radio astronomy could easily be selected.

Other proposals have been made which are perhaps more likely to be realized. Arthur C. Clarke (12), in an idea he attributes to Albert Robida 
originally made in the 19th century, proposes to use the moon as the screen for laser projections. He would project the image of children of all the world's races one at a time over a period of time to create an artwork called "Moon-Child." The project would cause no environmental degradation, no space debris, and no serious astronomical research work would be hampered (12). This is a good example of an artwork which, if carried out once, might be acceptable to the public, yet could easily be used for commercial advertising purposes and might be unacceptable if carried out repeatedly. There are currently no regulations or legislation which would control such kinds of activities. It was the Eiffel competition which attracted the first serious attention of astronomers to space art proposals. Strong objections were raised by Paul Murdin (13), and additional cautions were provided by astronomer Jean Claude Pecker (14). Pecker, however, noted that other proposals have attracted the attention of astronomers. These have included Project Westford, involving the proposed launch of millions of metallic needles to aid telecommunications, Project Able to illuminate Viet Nam using a geostationary reflector, and Project Centaur to explode an A-Bomb to study particles in the ionosphere.

\section{ART ON THE EARTH TO BE VIEWED FROM SPACE}

There are a few art objects which have been made on earth to be viewed from space. In 1980, Pierre Compte proposed a series of works (Project Horus) consisting of floating prism retro-reflectors to create artworks for astronauts to view (9). In 1981 Tom Van Sant, as part of the first Sky Art Conference (4), laid a large reflecting "eye" on the desert floor of the California Shadow Mountains. The object was photographed by the Landsat satellite; had there been astronauts in orbit at the time, they would have viewed Tom Van Sant's "Reflections in Space." Van Sant followed this in 1986 with a second piece titled "Desert Sun" at the Desert Sun/Desert Moon Event (4). Forty eight mirrors, each 2 feet by 2 feet, reflected sunlight back to the G-6 satellite in geostationary orbit. Images of the earth showing the reflected sunlight were transmitted via the National Optical Astronomy Observatories (NOAO) to viewers in Los Altos, California.

In 1982, sculptor Ezra Orion proposed to NASA the use of one of the Viking Landers on the surface of Mars to create a sculpture by piling Martian rocks on top of each other (15). The act would have required that some 200 individual radio commands be sent to Viking over roughly a day's duration. With this very simple act, NASA could have extended the range of human sculpture by 90 million kilometers. The cultural value of such an act would seem to justify the minimal costs and risks involved.

\section{ART MADE IN SPACE FOR USE IN SPACE OR VIEWED FROM SPACE}

Eventually, as space is colonized, most space art will be intended for space travelers. Albert Notarbolo made detailed designs in 1971 for a project, "Earthlog" to provide an orbiting repository of mankind's existence and accomplishments (5). In the early 1960 s, artist Morris Graves worked with NASA to develop artworks to be incorporated in satellites and probes, but none of these were realized (16). A Dutch artist, Paul Van Hoeydonck, sent a small plaque 
which was left on the moon in 1971 (16). In the same spirit as the records which accompanied the Voyager spacecraft as it left the solar system, these artists express one of the age-old goals of artists: to leave an imprint of their existence to be viewed by later civilizations.

Architects are already becoming involved in designing space habitations. Architects have begun to address architectural issues involved in structures for long-term habitation in orbit or on the moon (16). In Houston, the Sasakawa International Center for Space Architecture has recently opened (18) to prepare designers for the new problems posed by architecture of space structures and buildings.

\section{DISCUSSION}

The only position that can be taken, in my opinion, is that all space activities must be carried out in conformance with established international treaties and national legislation. Artists, like anyone else, should conform to these constraints, but should not be singled out. An excellent review of the present status of the agreements governing the activities of nation states on the moon and other celestial bodies has been given recently by Eilene Galloway (19).

At this date the following treaties govern activities in space:

1) Treaty of Principles Governing the Activities of States in the Exploration and Use of Outer Space, including the Moon and Other Celestial Bodies (October 10,1967). This treaty was ratified by 96 parties. Under Article VI of the Treaty, governments are required to authorize and exercise continuing supervision over space activities, both governmental and non-governmental. In the U.S.A. it is the Department of Transportation that must issue licenses and ensure that provisions on insurance, safety and risk factors, national security and other factors are met.

2) Agreement on the Rescue of Astronauts, the Return of Astronauts and the Return of Objects Launched into Outer Space (December 3, 1968). Ratified by 88 parties.

3) Convention on International Liability for Damage Caused by Space Objects (September 1, 1972). Ratified by 81 parties.

4) Convention on Registration of Objects Launched into Outer Space (September 15, 1976). Ratified by 43 parties.

5) Agreement Governing the Activities of States on the Moon and Other Celestial Bodies (December 5, 1979). Ratified by 7 parties, not including the U.S.A., the U.S.S.R., Japan, or any of the European space powers.

The fact that in nine years only seven nations ratified this last agreement is in sharp contrast to the widespread acceptance of the previous space treaties. I would argue that this recent reluctance of the space powers to enter into international agreements governing space activities is a far larger threat to the work of astronomers and space scientists than any proposal presented by artists to date. Over the next fifty years, we are likely to witness the gradual commercialization and militarization of the near-earth environment, significant impacts on the moon and nearby planets. Without an evolving international consensus about the regulations governing these activities, it is highly likely that commercial and military activities will impact both space-based and ground-based 
astronomical work.

In 1981, a group of artists led by Otto Piene, Elizabeth Goldring and Lowry Burgess, started the series of Sky Art conferences culminating in the signing of the Sky Art manifesto by several hundred artists (4). The manifesto was presented at the 1986 UNESCO Conference on Culture in Space. At the same conference French artist Jean-Marc Phillippe (20) proposed the establishment of a Space Art Ethics committee to develop an understanding of all environmental and cultural constraints on space art. I believe that such a group could plan a useful role in developing the necessary guidelines for space art of the future.

\section{ACKNOWLEDGEMENTS}

I would like to thank James Pridgeon, Jean-Marc Phillipe, Pierre Compte and Joe Davis for unpublished material. In researching this article, I have become aware of how little documentation exists on the work of space art pioneers. I encourage artists and others to send me information on other work and corrections of act or attribution.

\section{REFERENCES AND NOTES:}

(1) J. Pridgeon, "The Artistic Potential of the Space Station Program; Report to the Space Station Task Force for Innovative Utilization of the Space Station Program." NASA Contract NASW-3746 Final Report, 1983.

(2) Larry Polansky, "Jim Tenney and Space Travel," Perspectives of New Music, 25, pp.436-438, 1987.

(3) F. J. Malina, "On the Visual Fine Arts in the Space Age," Leonardo, 3, pp.323-325, 1970 (3).

(4) Elizabeth Goldring, "Desert Sun/Desert Moon and the Sky Art Manifesto," Leonardo, 20, pp.339-348, 1987.

(5) Albert Notarbolo, "Some Proposals for Art Objects in Extraterrestrial Space," Leonardo, 8, pp.139-141, 1975.

(6) Joe Davis, "The Last Getaway Specials: NASA and the Artist," Leonardo, 1989 , in press.

(7) Lowry Burgess, "Burgess: The Quiet Axis," (Montreal: Precare, 1987).

(8) An Eiffel Tower in Space; Competition Rules, Paris, 1986.

(9) Pierre Compte, "Leonardo in Orbit: Satellite Art," Leonardo, 20, p.1721, 1987. See also Pierre Compte, "Reply to Jean Claude Pecker," Leonardo, 20, p.298, 1987.

(10) C. Coles and A. Jefferson, "The Space Chronometer Finalist in the Eiffel Competition," Leonardo, in press, 1989.

(11) Letter from James Pridgeon to the author, July 9, 1988. Pridgeon identifies three issues raised by astronomers: a) Light pollution, potential damage to sensitive ground-based detectors; b) Domino theory: One space sculpture may not be a problem, but there will be no way to prevent gradual worsening of the problem; c) Space is a natural wilderness that should not be polluted by unnecessary human artifacts. 
(12) Arthur C. Clarke, letter to the author, March 24, 1988. Proposal submitted in response to the Call for Proposals for "Project 2001: A monument to celebrate the third millenium," Berkeley, California.

(13) Paul Murdin, "Art vs Science: The Battle for the Stars," New Scientist, Vol. 113, 1551, p.60-61, 1987. See also Paul Murdin, The Observatory, 107, pp. 181-182 for a discussion.(14) J. C. Pecker, "Comments on 'Leonardo in Orbit: Satellite Art'," Leonardo, 20, p.298, 1987.

(15) Ezra Orion, "Sculpture in the Solar System: From geologically based earthworks to astro-sculpture," Leonardo, 18, pp.157-160, 1985.

(16) Miriam Seidel, "The Space/Time Continuum Revisited," Lightworks, 7, pp.40-45, 1985.

(17) Tomas Brix and Michal Brix, "On Modular Structures on the Moon," Leonardo, 5, pp.43-45, 1972.

(18) See Leonardo, 21, p.205, 1988. The Sasakawa International Center for Space Architecture is located in Room 122 ARC, University of Houston, 4800 Calhoun, Houston, TX 77004, USA.

(19) Eilene Galloway, "The Present Status of the Agreement Governing the Activities of States on the Moon and Other Celestial Bodies," presented at the International Colloquium on Environmental Aspects of Activities in Outer Space, Cologne, Federal Republic of Germany, May 1988.

(20) Jean-Marc Philippe, "L'Art Spatiale et ses Enjeux," presentation to the UNESCO Conference on Culture and Space, November 3, 1986. Jean-Marc Philippe also presented his concept for a Space Art Ethics Committee at the European Conference on Philosophy and the Franco-European Cultural Summit in 1986. It was proposed that the Committee would be based at the European Academy of Sciences, Arts and Literature in Paris. 